\title{
Adaptations and Experiments by the Semarang Music Ecosystem in Facing Covid-19 Pandemic
}

\author{
Gregorius Tri Hendrawan Manurung ${ }^{1 *}$, Khothibul Umam $^{1}$, Fajrul Falah $^{1}$, and Suharyo ${ }^{1}$ \\ ${ }^{1}$ Department of Indonesian Literature, Faculty Humanities, Diponegoro University, Semarang, \\ Indonesia
}

\begin{abstract}
This research was conducted in order to identify forms of adaptation and experiment by the Semarang music ecosystem in facing impacts of Covid-19 pandemic. This research adopted Sociology of Art approach by which art product is not viewed as worked by an individual, but rather, it is produced by an art world. This research focused on three aspects of music ecosystem, namely production and release, concert, and distribution. Data were collected by conducting observation and in-depth interviews. Observation was conducted to collect data concerning adaptive and experimental practices implemented by music actors in Semarang during the pandemic. Meanwhile, in-depth interviews were implemented to synchronize data of adaptations and experiments conducted by the Semarang music ecosystem.
\end{abstract}

\section{Introduction}

Spreading in Indonesia since March 2020, the Covid-19 pandemic has been causing changes in various aspects of human life. The government issued a policy that restricts social gathering or crowding in a public area. Based on the data collected by Koalisi Seni Indonesia (Indonesian Coalition of Arts), 234 art activities had been canceled because of the Covid-19 pandemic, and 112 of them were musical shows [1]. 37.000 artists or art workers lost their income amidst the pandemic, and 189.586 art and creative workers, from musicians, stage crews, and film crews, were fired and sent home [2].

In Semarang, the municipal administration issued the Pembatasan Kegiatan Masyarakat (Restriction of Social Activities) regulation in April 2020. This policy caused various musical shows to create crowds or gatherings cannot be performed. Either mainstream or independent music actors have been suffering from its impacts. The limited condition required changes of practices by musical actors and performance artists to uphold their existence [3].

Amid the social gathering restriction, many music actors have been adapting to and experimenting with this condition. Transfer of musical practices or shows from physical space to digital space has begun to be carried out by music actors in Semarang.

Several musicians in Semarang performed Live Session virtually during the Covid-19 pandemic, independently or in collaboration with other parties. Soegi Bomean, Santikarisma, and Tridhatu are, among others, the musicians who performed virtual concerts. There is

\footnotetext{
* Corresponding author: gregoriusthmanurung@students.undip.ac.id
} 
also Bunyi dari Rumah (Sound from Home) routine program which invites Semarang musicians to perform music shows virtually.

Besides the virtual shows, several experimental concerts were performed in Semarang. On December 24th, 2020, Wiwiek n Friends performed a live concert attended directly by audiences by obeying health protocols. In their attempts at getting around the live concert, Maloree and Santikarsima performed hearing sessions for their newest songs. On July 29th, 2020, the first drive-in concert, Mahkota Drive-In Charity Concert, was performed in PRPP Semarang [4].

From the data mentioned above, several adaptive and experimental practices carried out by the Semarang music ecosystem actors in facing the Covid-19 pandemic can be shown. These articles aim to scrutinize the adaptive and experimental practices by the Semarang music ecosystem in facing the Covid-19 pandemic, also to find the impact of these practices on the development of the Semarang music ecosystem.

\section{Literature Study}

It can be said that amid the Covid-19 pandemic, researches concerning Indonesian music focused on either cultural change or the music ecosystem are rare. In December 2020, Puji Hastuti published an article entitled "Dynamics of Ecosystem of Indie Music Industry in Jakarta and Its Surroundings during the First Outbreak of Covid-19 Pandemic" [5]. This article scrutinizes adaptive practices adopted by the Jakarta independent musicians in facing the Covid-19 pandemic.

Using an anthropological approach, Hastuti recorded and analyzed adaptive phases and practices taken within the Jakarta independent music ecosystem during the first outbreak of the Covid-19 pandemic. Adaptive practices taken by the Jakarta independent music ecosystem are (1) communal solidarity, (2) creative capability for habitual adaptation, (3) joint, digital space exploration, and (4) contemplative time for creating or presenting new works.

In June 2020, Dadang Dwi Septiyan wrote an article about music's cultural changes/evolution in the middle of the Covid-19 Pandemic. Septiyan's research concluded that Covid-19 Pandemic harmed the continuity of music culture. The absence of physical performances reduced human interactions that led to dehumanization. On the other hand, this condition benefit some people due to reducing the production cost of music [6]

Meanwhile, research that discusses the Semarang music ecosystem's adaptive and experimental practices is nonexistent as the authors searched. Therefore, together with data of practices presented above, this research was importantly conducted to understand the dynamics of the Semarang music ecosystem during the Covid-19 pandemic..

\section{Research Method}

This research is on-field research. The research method adopted here is Sociology of Art. Sociology of Art does not view artwork as an individual or personal product but, instead, as a collective work in an art world [7]. This research also reveals inter-actor and inter-aspect relations within the art ecosystem, also discussed or examined people with specific involvement in art activities and other people outside art activities who were involved in the cultural phenomenon that influenced the art activities [8][9][10]. Aspects to be scrutinized here are related to record release, distribution, and exhibition (concert). Data were collected through observations and in-depth interviews. Observations were conducted to collect data on practices carried out by Semarang music ecosystem actors during the Covid-19 pandemic. Meanwhile, in-depth interviews were carried out to synchronize adaptations and experiments 
conducted by the Semarang music ecosystem. These data were analyzed in order to determine inter-actor and inter-aspect relations in the Semarang art world.

\section{Discussion}

\subsection{Adaptation and Optimization of Digital Space}

One of the most dominant adaptive activities amid the Covid-19 pandemic was a virtual concert. An experimental group in Semarang, Tridhatu, used virtual concerts to get around far distances between musicians and organizers/audiences. On December 5th, 2020, Tridhatu performed in a virtual concert organized by Rahasia Mafiusa (Mafiusa Secret), a South Africa nonprofit organization. This concert, entitled From Darkness to Light: STAND UP-WISE UP, unified 15 Indonesia and South African artists. Aristya Kusuma Verdana, Tridhatu personnel, said that besides presenting its works to the public beyond Indonesia, optimizing digital space during the pandemic can put creativity poles together from various countries. Verdana found that this condition can become an opportunity for better comprehending the working mechanism of the digital world and optimizing it for career progress.

The utilization as identified by Verdana had been done by Irama Records, the digital music distributor (aggregator) in Semarang. On December 18th, 2020, Irama Records collaborated with Hills Collective to simultaneously release 14 songs composed by Semarang musicians, which became their roster in a program entitled Koloni. As the official aggregator, Irama Records did pitching on Spotify Asia to enlist all Koloni's songs on Spotify's official playlist.

According to a manager of Irama Records, Sani, enlisting songs into Spotify's official playlist will increase the number of audiences for the songs. This was proven for several rosters of Irama Records. One of the Semarang jazz musicians, Naufalbahir, has survived on Spotify's official playlist, "Jazz Anak Negeri." Until May 21st, 2021, his song entitled "Cukup" won 43,505 audiences, whereas other songs obtained 1,000 on average.

All songs recorded in Koloni had successfully enlisted in Spotify's official playlists entitled "Fresh Finds Indonesia" and "New Music Friday."

\subsection{Cross-Sector Collaboration}

Before the Covid-19 pandemic in Indonesia, one of the music group newcomers in Semarang, Soegi Bomean, had signed contracts with a company to conduct music shows in several cities in Indonesia. With the enactment of social gathering restriction regulation, these contracts were annulled.

According to Erick Parkers, who takes the role as manager for Soegi Bomean, PyongPyong, and several other bands in Semarang, the most affected by this condition are band crews whose livelihood depends on concerts. According to Erick, several offers for taking part in virtual concerts had helped bands survive financially, for which they are paid.

Erick and several bands under his management collaborated with other creative industry actors in non-music sectors, such as culinary and clothing lines, to overcome the band's financial difficulties.

On February 12nd 2021, Soegi Bomean collaborated with Semarang's coffee shop, Canoffee Coffee, in launching two drink products. The products are Welas (non-coffee) and Renjana (coffee-based). Soegi Bomean created brand names, tastes, and recipes for the drinks. There is a merchandise bonus in the form of a tote bag in their sales, a product that resulted from a collaboration between Soegi Bomean and Canoffee Coffee, gifted to a buyer who bought these two products with Rp. 150,000.00 minimum purchase. The release of 
Welas and Renjana took place one week after the grand opening of Canoffee Coffee's new outlet in which Soegi Bomean was performing.

The practices adopted by Soegi Bomean and Canoffee Coffee are very similar to those conducted by a Jakarta band, Goodnight Electric [5]. Goodnight Electric collaborated with Jakarta's chocolate producer, Piplitin Cocoa, to release a chocolate product named Dopamin Baked Cheese Choco Bar.

In addition, Erick said that collaboration would be reached between Pyong-Pyong and a Semarang clothing brand, Horny Cupcakes, to release merchandise relevant to the most popular song of Pyong-Pyong.

\subsection{Collaboration as Principle of Experimentation}

The manager of Irama Records, Sani, said that amid the Covid-19 pandemic, collaborative practices have become more important to do. This principle underlies the Koloni program. Besides Irama Records, Wiwiek n Friends and Urban Looplab applied this principle in their experiments.

On December 24th, 2020, Wiwiek n Friends performed a physical concert in Artotel Gajahmada Semarang. This concert was performed by obeying health protocols. The number of audiences was limited to no more than 50, the audiences' body temperature was measured before entering the room, and the distance between audiences and performers was closely observed.

Wiwiek n Friends' vocalist, Radika, said that this physical concert could be realized because of all parties' collaboration during preparation and exhibition. In preparing this concert, they were supported by links of friends who are pursuing music and theatre.

The Artotel Gajahmada Semarang played an enough crucial role in this concert preparation. In addition to providing a venue capable of accommodating physical distancing, Artotel had also taken care of show permits so that this concert might be conducted.

To assure implementation of the health protocols, Artotel invited police officers to the venue to directly oversee the course of the concert. Radika needs to oversee the concert by the authorities and heath protocols being observed closely.

Practices adopted in the Wwiek n Friends' physical concert can be viewed as a potential concept of the triple helix, in which three main actors in the music ecosystem (government or authority, private/industry, and music community) can collaborate in activating music space and activities in a particular region [11]. Although it could not be classified yet as idealistic triple helix practice, it is a pioneering project toward a more idealistic practice.

In the independent realm, there was an experiment conducted by Urban Looplab. Urban Looplab is a Semarang-based media with a focus on the creative industry. In addition to being a media, Urban Looplab also initiated several activities irrelevant to information production. Among the activities is the hearing session for newly-released singles of the Semarang musicians.

Urban Looplab had collaborated with Santikarisma and Maloree in performing hearing sessions for single. Chief editor of Urban Looplab, Dzul F. Ahmad, said that a hearing session could become an attempt to get around the nonexistence of concerts amid the pandemic.

In addition, hearing sessions can bring musicians closer to other ecosystem actors, namely media and audiences. During each hearing session, discussions were taking place between musicians, media, and audiences. According to Ahmad, the matters being discussed are music matters and artworks accompanying the single release. During the hearing session of the Maloree's single, "Wounds," many Semarang local media were present, and they reported the single release. 


\section{Conclusion}

Minimal conditions during the Covid-19 pandemic have indirectly created various potentials in developing the music ecosystem. Inter-actor and cross-sector collaborations in the music ecosystem have been pioneered by actors of the Semarang music ecosystem, something that could not be imagined before. Optimization of digital technology and space has also given birth to new practices capable of supporting music ecosystem sustainability. These potentials will undoubtedly be very valuable for the Semarang music ecosystem growth if they were being explored and developed continuously, even when the Covid-19 pandemic in Indonesia peters out or ends.

\section{References}

1. Koalisi Seni Indonesia. "Acara Seni yang Batal dan Ditunda Akibat Pandemi". https://koalisiseni.or.id/acara-seni-yang-batal-dan-ditunda-akibat-pandemi/ (2020).

2. Hafez Gumay. "Menyoal Kebijakan Kartu Prakerja untuk Seniman Terdampak Pandemi". https://koalisiseni.or.id/menyoal-kebijakan-kartu-prakerja-untuk-senimanterdampak-pandemi/ (2020).

3. Luki Safriana. "Tantangan Berat Seniman Pertunjukan di Masa Pandemi Corona". https://katadata.co.id/muchamadnafi/indepth/5e9a41c87f85e/tantangan-berat-senimanpertunjukan-di-masa-pandemi-corona (2020).

4. Angling Adhitya Purbaya. "Konser Drive-In Pertama di Indonesia Digelar di Semarang". https://hot.detik.com/music/d-5113571/konser-drive-in-pertama-di-indonesia-digelar-disemarang (2020).

5. Puji Hastuti. "Dinamika Industri Musik Indie Jakarta dan Wilayah Sekitarnya Pada Masa Pandemi Covid-19 Gelombang Pertama" in Jurnal Masyarakat Indonesia, 46 (2). 221239 (2020).

6. Dadang Dwi Septiyan. "Perubahan Budaya Musik Di Tengah Pandemi Covid-19" in Jurnal Musikolastika: Jurnal Pertunjukan Dan Pendidikan Musik, 2 (1). $31-38$ (2020).

7. Howard S. Becker. Art Worlds. 7-14 (2005).

8. Rober Escarpit. Sosiologi Sastra. 1-2 (2005)

9. Sapardi Djoko Damono. Sosiologi Sastra: Suatu Pengantar Ringkas. 3-5 (1978).

10. Janet Wolff. The Social Production of Art (Second Edition). 40-48. (1993)

11. The British Council. "Research Summary: The Mapping of Indonesia Music Sector Ecology". https://www.britishcouncil.id/en/music-research-mapping-indonesian-musicsector-ecology. 28-30 (2020). 